\title{
Comparative effect of ion calcium and magnesium in the activation and infection of the murine macrophage by Leishmania major
}

\author{
HENRIQUE LANZA ${ }^{1}$, SANDRA R. AFONSO-CARDOSO ${ }^{1}$, ADRIANO G. SILVA $^{1}$, \\ DANIELLE R. NAPOLITANO ${ }^{1}$, FOUED S. ESPÍNDOLA ${ }^{2}$, JANETHE D.O. PENA ${ }^{1}$ and \\ MARIA A. SOUZA ${ }^{1 *}$
}

1. Laboratório de Imunologia, Instituto de Ciências Biomédicas and

2. Laboratório de Bioquímica e Biologia Molecular, Instituto de Genética e Bioquímica, Universidade Federal de Uberlândia, Uberlândia, MG, Brazil

\begin{abstract}
Amastigotes of Leishmania major have a great ability to evade destruction in host cells. This study investigated the activation in resident, inflammatory macrophages and $\mathrm{J} 774$ cells in vitro treated with lipopolysaccharide (LPS), soluble Leishmania antigen (SLA), calcium ionophore (CaI) and magnesium $\left(\mathrm{Mg}^{2+}\right)$ alone or combined. An increase in nitric oxide (NO) production was observed in J774 or inflammatory macrophages treated with LPS alone or in combination with SLA and CaI. The same treatments did not affect the NO release by resident macrophages. There was no interference in uptake of L. major but CaI decreased intracellular proliferation of the parasite. This study demonstrated the importance of $\mathrm{CaI}$ in decreasing $L$. major proliferation inside murine macrophages while $\mathrm{Mg}^{2+}$ seemed to increase parasite proliferation. These finding may help to understand the events involved in host cells' clearance of this pathogen.
\end{abstract}

Key terms: calcium, Leishmania major, macrophage, magnesium, nitric oxide.

\section{INTRODUCTION}

Leishmania are dimorphic tripanosomatidae (amastigotes and promastigotes). When in contact with phagocytic cells of their vertebrate hosts, they replicate as nonflagelate amastigotes inside endocytic organelles called parasitophorous vacuoles (Alexander and Russell, 1992; Probst et al., 2001; Chang et al., 2003). Metacyclic promastigotes are introduced into the organism by sand fly bites, after the parasites are phagocytosed by macrophages through interactions with CR3 receptors and also parasite glycoproteins and glycolipids, such as gp63 and lipophosphoglycan (LPG), respectively (Turco and Descoteaux, 1992).

Among the various products of macrophage activation, nitric oxide (NO) is an important mediator of a number of biological functions including tumoricidal effects, vascular relaxation, neurotransmission, immunosuppression and cytotoxic activity against several pathogens, including Leishmania major, Plasmodium falciparum, Schistosoma mansoni and Toxoplasma gondii (Vouldoukis et al., 1995; Huang et al., 1998; Carreras et al., 2000; Rubbo et al., 2000).

Macrophages play a pivotal role in the course of leishmaniasis, acting not only as host cells but also as antigen-presenting cells capable of modulating the specific immune response. Macrophages also act as effector cells against the parasite, after proper activation by cytokines such as interferon (IFN)-gamma and tumor necrosis

Correspondence to: Maria A de Souza, Laboratório de Imunologia, Universidade Federal de Uberlândia, 
factor (TNF)-alpha (Drapier et al., 1988; Auger and Ross, 1991; Rogers et al., 2002). Calcium ionophore has been shown to mimic the effect of IFN-gamma in priming macrophages for leishmanicidal activity (Buchmüller-Rouiller and Mauël, 1991). However, questions regarding the mechanisms of parasite persistence for several years in the host and the strategies devised by Leishmania to escape and/or modulate specific immune responses remain unclear.

In the present work we analyzed the microbicidal activity of macrophages during infection by Leishmania major, evaluating macrophage activation as well as the ability of these cells to impair parasite replication.

\section{MATERIALS AND METHODS}

\section{Animals and parasites}

Inbred strains female of BALB/c mice at 68 weeks of age were used for obtaining resident and inflammatory macrophages. Leishmania major, strain MRHO/SU/59/P, were obtained from footpads of infected $\mathrm{BALB} / \mathrm{c}$ mice and cultivated in complete RPMI medium, consisting of RPMI 1640 medium supplemented with $2 \mathrm{mM}$ of Lglutamine (Life Technologies, Grand Island, N.Y.), $10 \%$ fetal bovine serum (Life Technologies), $100 \mathrm{U} / \mathrm{ml}$ of penicillin (Sigma Chemical Co., St Louis, MO, USA), $100 \mu \mathrm{g} / \mathrm{ml}$ of streptomycin (Sigma), $1 \mathrm{mM}$ of sodium pyruvate and $100 \mathrm{mM}$ of MEM non-essential amino acids (Life Technologies) at $25^{\circ} \mathrm{C}$. All animal experiments were performed according to the standards of the Colégio Brasileiro de Experimentação Animal (CoBEA).

\section{Soluble antigen of Leishmania major}

Soluble Leishmania antigen (SLA) was prepared as described elsewhere (Scott et al., 1987), with modifications. To summarize, stationary growth phase L. major promastigotes obtained from culture in complete RPMI medium were washed in Hanks balanced salt solution (HBSS, Life
Technologies) and centrifuged for 15 minutes at $3000 \times \mathrm{xg}$ and $4{ }^{\circ} \mathrm{C}$. Parasite concentration was adjusted to $1 \times 10^{9}$ parasites in HBSS containing $50 \mu \mathrm{g} / \mathrm{ml}$ of leupeptin (Sigma) and $1.6 \mathrm{mM}$ phenylmethylsulphonyl fluoride (PMSF, Sigma). After 10 minutes in ice bath, parasites were sonicated with 4 cycles of 1 minute each. The lysate was centrifuged for 15 minutes at $3000 \mathrm{x} g$ and $4{ }^{\circ} \mathrm{C}$. The supernatant was harvested and centrifuged at $20000 \mathrm{xg}$ at $4^{\circ} \mathrm{C}$ for 30 minutes. The supernatant then filtered through $0.22 \mu \mathrm{m}$ membranes and protein concentration was determined by the Lowry method (Lowry et al., 1951). SLA was stored at $-70^{\circ} \mathrm{C}$ until use.

\section{Cell culture}

Inflammatory macrophages were obtained from $\mathrm{BALB} / \mathrm{c}$ mice previously inoculated with 3\% Thioglycollate medium (Sigma), while the resident macrophages were obtained from the peritoneal fluid of untreated BALB/c mice. The J774A.1 cells were purchased from ATCC (Rockville, MD, USA). Cells $\left(5 \times 10^{5}\right)$ were cultured in complete RPMI medium in a humidified chamber at $37^{\circ} \mathrm{C}$, containing $5 \%$ $\mathrm{CO}_{2}$, in the presence of either $10 \mu \mathrm{g} / \mathrm{ml}$ lipopolysaccharide (LPS, Sigma), $4 \mu \mathrm{g} / \mathrm{ml}$ of SLA, $1 \mu \mathrm{M}$ calcium ionophore A23187 (CaI, Sigma), $1 \mu \mathrm{M}$ magnesium chloride $\left(\mathrm{Mg}^{2+}\right.$, Vetec, Brazil) alone or in combination, in a total volume of $200 \mu \mathrm{l} / \mathrm{well}$. The stimuli concentration was performed in accordance with Reis et al. (2001). After 48 hours, culture supernatants were collected for nitrite/nitrate $\left[\mathrm{NO}_{2}{ }^{-}+\mathrm{NO}_{3}^{-}\right]$measurements based on the Griess method (Martinez et al., 2000). Alternatively, cells were infected with stationary growth phase L. major promastigotes $\left(5 \times 10^{6}\right.$ parasites $/ 200 \mu \mathrm{l} /$ well $)$ for a period of three hours, then washed and fixed in cold methanol for 10 minutes. Cells were stained with Giemsa's solution or by immunofluorescence. The percentage of infected cells was determined by counting 500 cells in each experimental condition.

Nitrite assay for estimation of NO production

The concentration of stable nitrite, the end product from NO generation by effector 
macrophages, was determined according to the Griess method. Then, $50 \mu$ l of Griess reagent [1\% sulfanilamide in $2.5 \% \mathrm{H}_{3} \mathrm{PO}_{4}$ and $0.1 \%$ naphtylethylenediamine (NEED) in $\left.2.5 \% \mathrm{H}_{3} \mathrm{PO}_{4}(\mathrm{v} / \mathrm{v})\right]$ were added to $50 \mu \mathrm{l}$ of each sample, blank and standard curve in a 96-well microplate. The absorbance at $570 \mathrm{~nm}$ was measured using a microplate reader (Titertek Multiskan Plus) and software (Microplate Manager 4.0, Hercules, CA, USA). Nitrite content $(\mu \mathrm{M} /$ $5 \times 10^{5}$ cells) was quantified by extrapolation from the sodium nitrite standard curve in each experiment.

\section{Immunofluorescence assay}

For the immunofluorescence assay, fixed macrophages were rinsed with PBS pH 7.3 (3 times for 5 minutes each time) and permeated with $0.1 \%$ Triton X-100 for 10 minutes. After rinsing, cells were incubated for 45 minutes at $37^{\circ} \mathrm{C}$ with rabbit anti- $L$. major antibody diluted 1:100 in 2\% normal goat serum in PBS. After rinsing, cells were incubated with fluorescein isothiocyanate (FITC) conjugated goat anti-rabbit IgG (1:20 diluted). Slides were mounted in glycerol-N-propyl-galate, examined and photographed using the Olympus BX50F-3 microscope (Olympus Optical Co, LTD, Japan).

\section{Proliferation assay}

Resident and inflammatory macrophages (5 x $10^{5}$ cells/200 $\mu \mathrm{l} /$ well) were cultured. After an overnight incubation, non-adherent cells were removed by vigorous wash and LPS (10 $\mu \mathrm{g} / \mathrm{ml})$, SLA (4 $\mu \mathrm{g} / \mathrm{ml})$, CaI $(1 \mu \mathrm{M})$ and $\mathrm{Mg}^{2+}(1 \mu \mathrm{M})$ were added alone or combined. Macrophages were cultured for 48 hours, washed and infected with stationary phase L. major promastigotes $\left(5 \times 10^{6}\right.$ parasites $/ 200 \mu \mathrm{l} /$ well $)$ for three hours. Free parasites were removed, and cells were cultured for another 48 hours. Cells were then pulsed with $0.5 \mu \mathrm{Ci} /$ well of $\left[{ }^{3} \mathrm{H}\right]-$ Thymidine (New England Nuclear, Boston, MA, USA), incubated for 18 hours and then harvested (Cell Harvester, Cambridge Technology, Inc., USA). Radioactive incorporation was measured in a scintillation counter (Beckman LS 6500, Multi-Purpose Scintillation Counter, USA). Parasite proliferation was determined as the average of the proliferation index under each type of stimulus divided by the average of the proliferation index in the absence of stimulation (medium alone). Values above 1 indicated parasite proliferation within macrophages whereas values below 1 meant inhibition of parasite replication.

\section{Statistical analysis}

Data were analyzed by the ANOVA test (multiple comparisons) and results were expressed as the mean \pm standard deviation. Significance was considered when $\mathrm{p}<0.05$.

\section{RESULTS}

NO production as a marker of macrophage activation

High nitrite levels were detected in inflammatory macrophages cultivated in the presence of either SLA or LPS (205 \pm 18 and $193 \pm 3.5 \mu \mathrm{M}$, respectively) compared to the control (medium) $(58 \pm 4 \mu \mathrm{M}$, Fig. $1 \mathrm{~A}, \mathrm{p}<0.05)$. Incubation with $\mathrm{CaI}+\mathrm{LPS}$ (Fig. 1A, p<0.05) resulted in increase of NO release $(210 \pm 7 \mu \mathrm{M})$ compared to macrophages stimulated with CaI+SLA. In inflammatory macrophages treated with $\mathrm{CaI}, \mathrm{Mg}^{2+}$ or $\mathrm{CaI}+\mathrm{Mg}^{2+}$, no significant difference was observed in NO production (Fig. 1A). Resident macrophages showed the same levels of $\mathrm{NO}$ as the medium (Fig. 1B). In J774 cells stimulated with either SLA, LPS+SLA, CaI+LPS or $\mathrm{CaI}+\mathrm{Mg}^{2+}$, nitrite levels of $84 \pm 2.4,97 \pm 1.9,97 \pm 0.3$ and $77 \pm 0.5 \mu \mathrm{M}$, respectively, were detected which were also significantly higher than the medium (Fig. 1C, p<0.05). On the other hand, in $\mathrm{J} 774$ cells stimulated with $\mathrm{CaI}$ alone $(59 \pm 1.3 \mu \mathrm{M}$, Fig. 1C) a decrease in NO release was observed. Supernatants of J774 cells stimulated with LPS $(116 \pm 2.17 \mu \mathrm{M})$ or $\mathrm{LPS}+\mathrm{Mg}^{2+}(101 \pm$ $0.8 \mu \mathrm{M})$ presented NO levels highly significant (Fig. 1C, p<0.05) compared to the control (medium). 


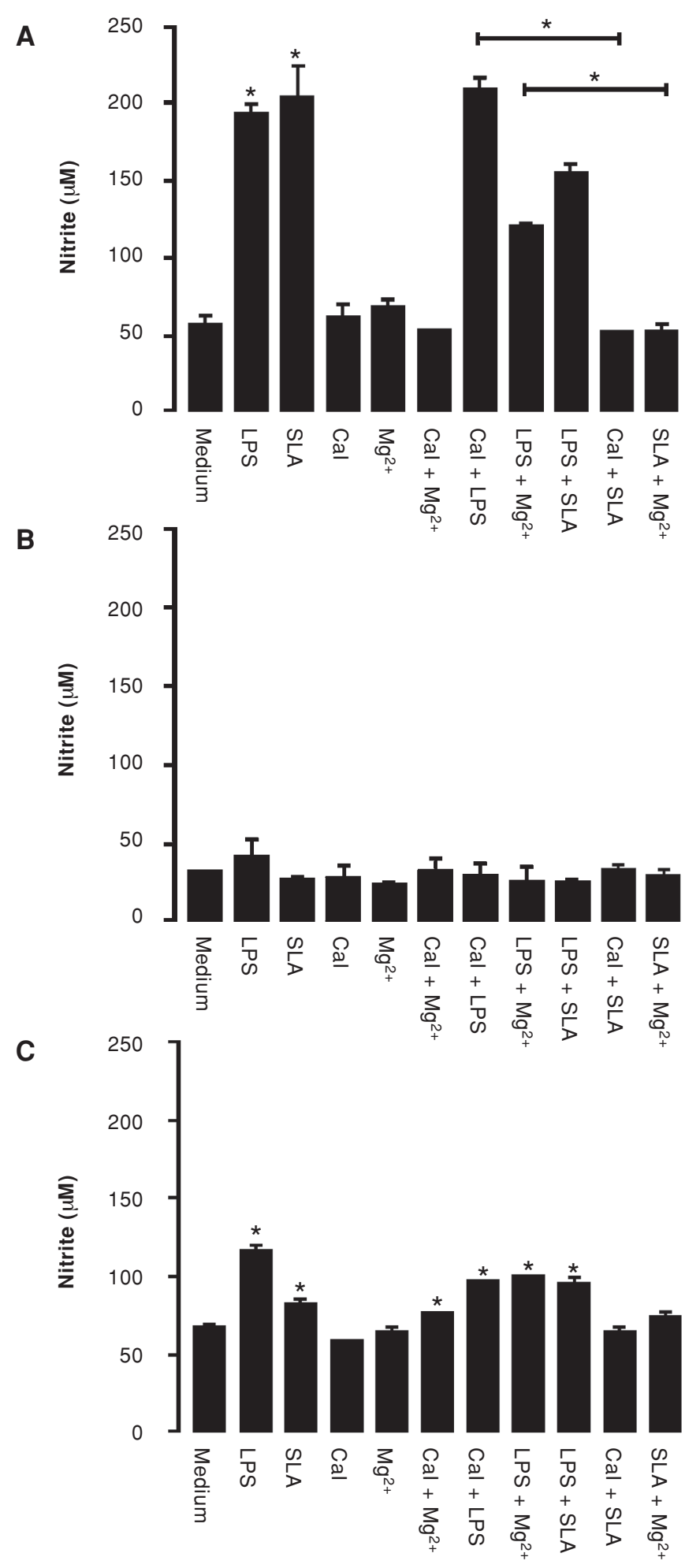

Figure 1. NO production. Inflammatory (A), resident macrophages (B) and J774 cells (C) were cultured in the presence or absence of the following treatments: LPS, SLA, CaI, $\mathrm{Mg}^{2+}, \mathrm{CaI}+\mathrm{Mg}^{2+}$, $\mathrm{CaI}+\mathrm{LPS}, \mathrm{LPS}+\mathrm{Mg}^{2+}$, LPS $+\mathrm{SLA}, \mathrm{CaI}+\mathrm{SLA}$ and SLA+ $\mathrm{Mg}^{2+}$. After 48 hours of culture, nitrite content was quantified by the Griess method. Columns show nitrite concentration (means \pm standard deviations from three independent experiments) expressed in $\left.\mu \mathrm{M} .{ }^{*}\right) \mathrm{p}<0.05$. 


\section{Uptake of Leishmania major}

Inflammatory macrophages stimulated with either SLA or SLA $+\mathrm{Mg}^{2+}$ had uptake rates 51.4 and $51.2 \%$, respectively when compared to the medium (Fig. $2 \mathrm{~A}, \mathrm{p}<0.05$ ). After pretreatment performed with the other stimuli, there were no significant differences compared to the medium. In J774 cells stimulated with SLA, SLA $+\mathrm{Mg}^{2+}$ or $\mathrm{CaI}+\mathrm{Mg}^{2+}$, uptake rates were $38 \%, 31 \%$ and $32 \%$, respectively (Fig. 2B). In J774 cells stimulated with CaI+LPS, CaI, CaI+SLA or LPS, the infection rates were $28 \%, 26.8 \%$, $21 \%, 20.2 \%$, respectively (Fig. 2B). These results were significant different compared from the medium $(12.8 \%)$. On the other hand, J774 cells stimulated with $\mathrm{Mg}^{2+}$, LPS + SLA or LPS $+\mathrm{Mg}^{2+}$ demonstrated uptake rates similar to those observed for medium (Fig. 2B). The Leishmania uptake in resident macrophages was similar to that in inflammatory macrophages (data not shown).
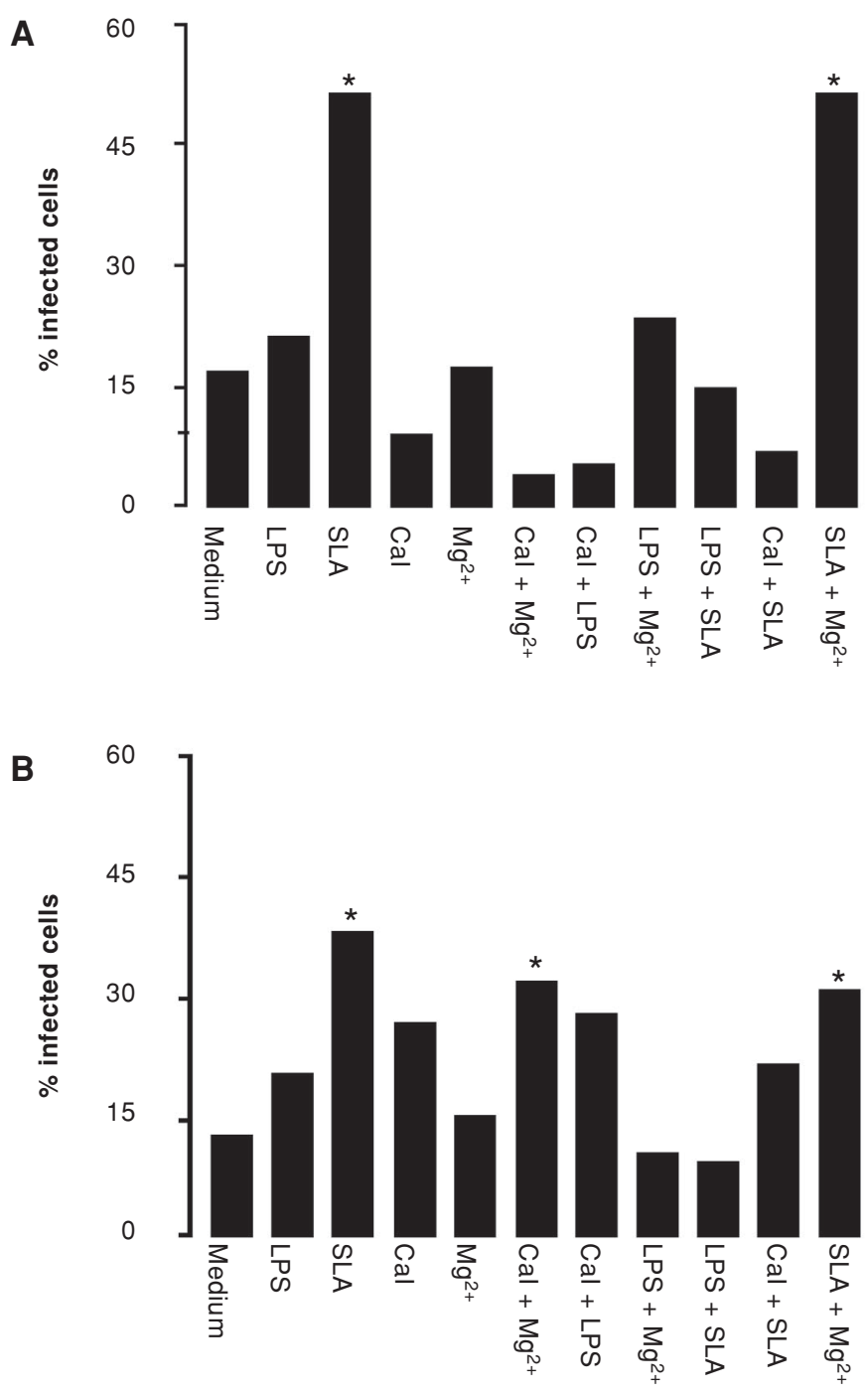

Figure 2. Cell infection percentage. Inflammatory (A) and J774 cells (B) were cultured for 48 hours in the presence or absence of treatments: LPS, SLA, CaI, $\mathrm{Mg}^{2+}, \mathrm{CaI}+\mathrm{Mg}^{2+}, \mathrm{CaI}+\mathrm{LPS}, \mathrm{LPS} /$ $\mathrm{Mg}^{2+}$, LPS+SLA, CaI+SLA and SLA+ $\mathrm{Mg}^{2+}$. Then the cells were infected by L. major for 3 hours, stained with Giemsa and analyzed under a microscope. The percentage of infected cells was determined by counting 500 cells from each treatment. $\left(^{*}\right) \mathrm{p}<0.05$. 


\section{Analysis of L. major proliferation index}

In inflammatory macrophages treated with LPS, SLA or CaI (Fig. 3A), there was a significant decrease $(\mathrm{p}<0.05)$ in the parasite proliferation index $(0.096,0.30$ and 0.20 , respectively). Conversely, in those macrophages treated with $\mathrm{Mg}^{2+}$ a significant increase in the parasite proliferation index was observed (3.05, Fig. $3 \mathrm{~A}, \mathrm{p}<0.05)$. No significant differences were observed in inflammatory macrophages treated with the other stimuli. In resident macrophages pretreated with CaI+LPS or CaI alone (Fig. 3B, $\mathrm{p}<0.05)$, proliferation indexes were significantly inhibited. Parasite proliferation was not evaluated in the J774A.1 immortalized cell line.

\section{Presence of L. major within activated macrophages}

In inflammatory macrophages as well as in J774 cells, parasites were observed in the cell periphery (data not shown). Figure 4 shows the presence of the parasite inside resident macrophages as long extensions of cytoplasm holding parasites at its ends, which was more evident in macrophages pre-treated with $\mathrm{CaI}+\mathrm{Mg}^{2+}$ (Fig. 4F), CaI (Fig. 4D), CaI+LPS (Fig. 4G) or $\mathrm{Mg}^{2+}$ (Fig. 4E).

\section{DISCUSSION}

Macrophage activation under different treatments was investigated to analyze the possible increase of the microbicidal capacity. In this experiment, inflammatory macrophages treated with $\mathrm{CaI}$ showed no significant NO production but parasite proliferation was decreased. While nitric oxide has been identified as a key molecule for leishmanicidal function of macrophages (Murray and Nathan, 1999), the data from the present study indicate that other pathways besides NO release are important for parasite clearance.

The microbicidal activity could be restored by excess $\mathrm{Ca}^{2+}$ rather than $\mathrm{Mg}^{2+}$, which suggests that changes in the concentration of cytosolic $\mathrm{Ca}^{2+}$ are sufficient to mediate the molecular events that lead to acquisition of
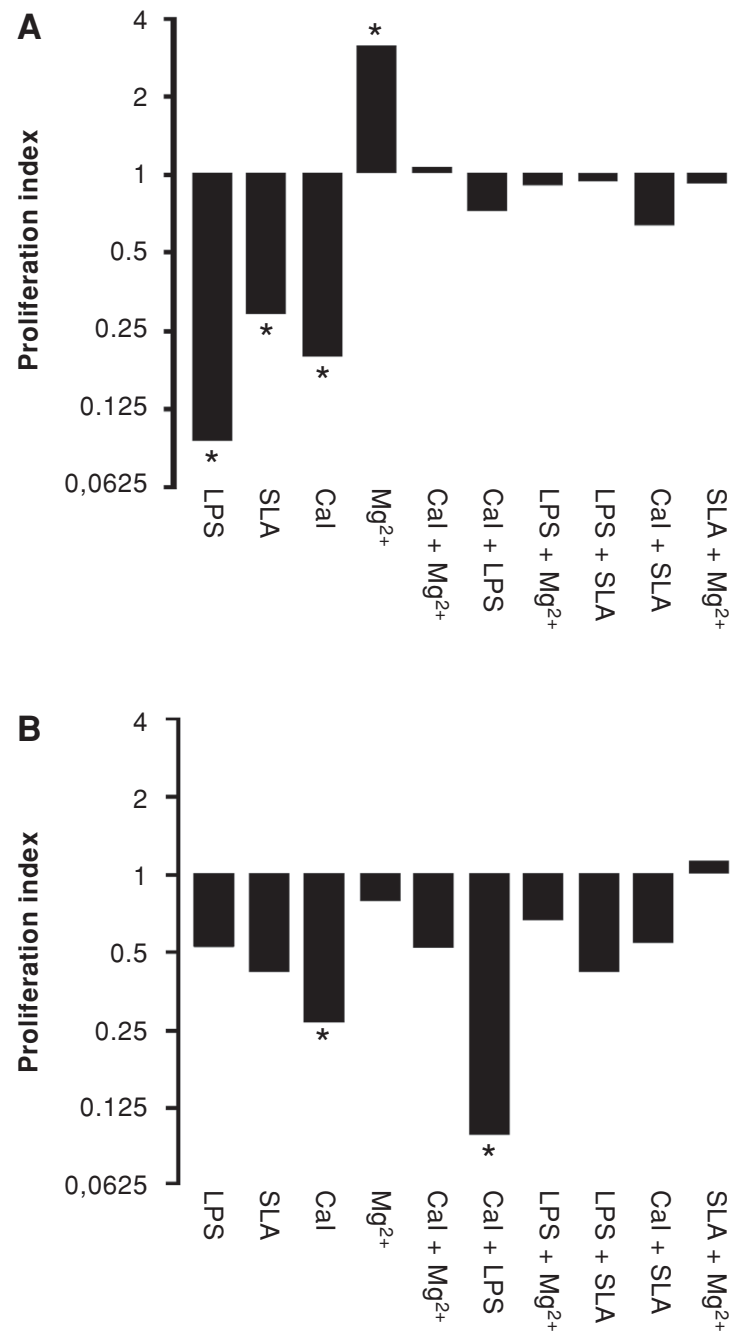

Figure 3. Proliferation index of $\boldsymbol{L}$. major in activated macrophages. Inflammatory (A) and resident (B) macrophages were cultured in the presence or absence of treatments: LPS, SLA, $\mathrm{CaI}, \mathrm{Mg}^{2+}, \mathrm{CaI}+\mathrm{Mg}^{2+}, \mathrm{CaI}+\mathrm{LPS}, \mathrm{LPS}+\mathrm{Mg}^{2+}$, $\mathrm{LPS}+\mathrm{SLA}, \mathrm{CaI}+\mathrm{SLA}$ and $\mathrm{SLA}+\mathrm{Mg}^{2+}$. After incubation for 48 hours followed infection by $L$. major during 3 hours, ${ }^{3}[\mathrm{H}]$ thymidine was added. Cells were harvested after 18 hours and counted. The results were expressed as the average proliferation rate with each treatment/ the average proliferation without treatment (proliferation index). Values over 1 indicate increasing intracellular growth of parasites. These data are representative from three other independent experiments. $(*) \mathrm{p}<0.05$. 

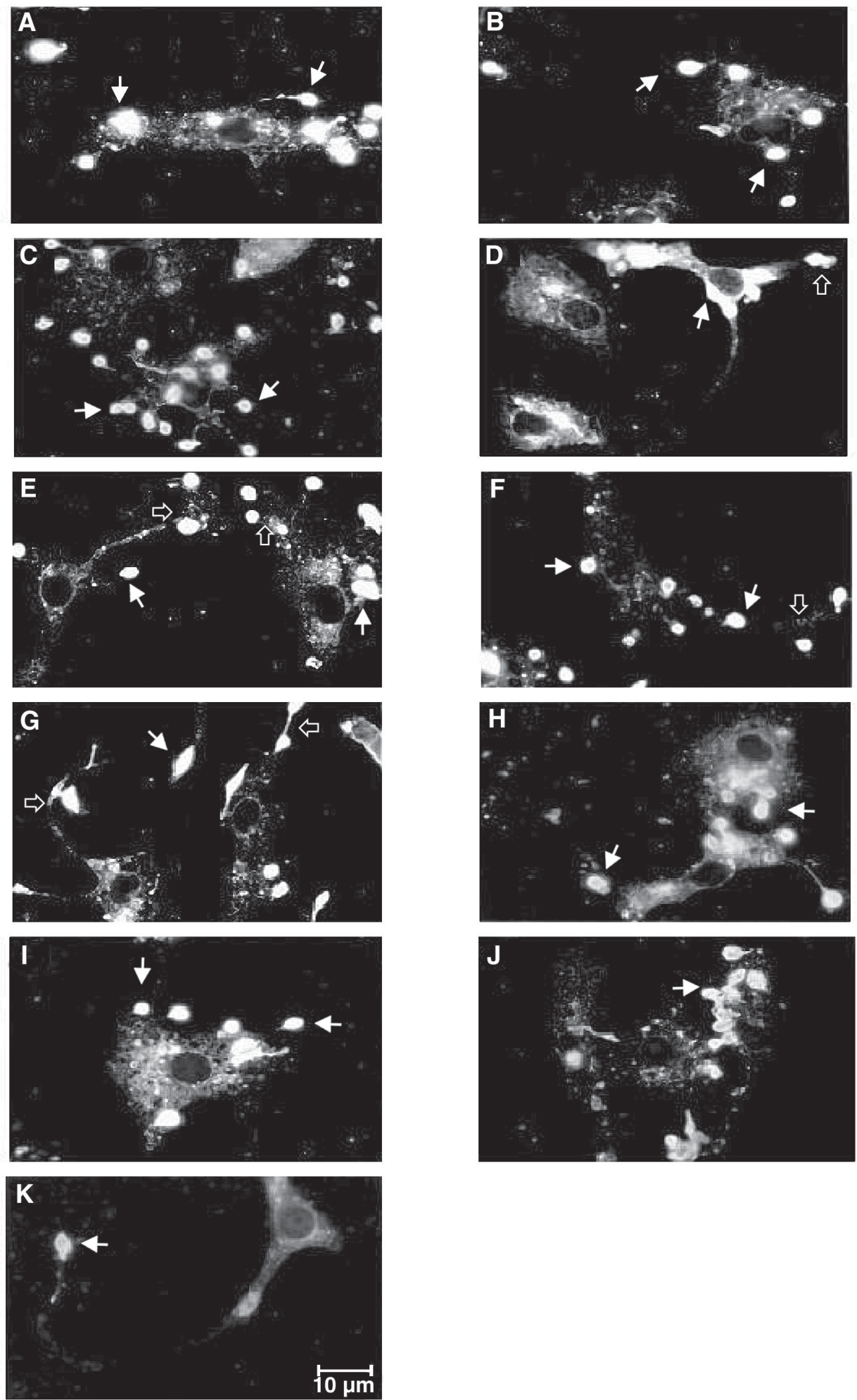

Figure 4. Immunofluorescence of intracellular amastigotes in resident macrophages. The resident macrophages were cultured in the presence of the medium (A), LPS (B), SLA (C), CaI (D), $\mathrm{Mg}^{2+}(\mathrm{E}), \mathrm{CaI}+\mathrm{Mg}^{2+}(\mathrm{F}), \mathrm{CaI}+\mathrm{LPS}(\mathrm{G}), \mathrm{LPS}+\mathrm{Mg}^{2+}(\mathrm{H}), \mathrm{LPS}+\mathrm{SLA}(\mathrm{I}), \mathrm{CaI}+\mathrm{SLA}(\mathrm{J}), \mathrm{SLA}+\mathrm{Mg}^{2+}$ (K) during 48 hours. After infection by L. major for 3 hours an immunofluorescence assay was performed. $(-)$ amastigotes. $(\Rightarrow)$ cytoplasm extensions. Bar, $10 \mu \mathrm{m}$. 
microbicidal potential (Buchmüller-Rouiller and Mauël, 1991). It has been demonstrated that an increase in intracellular $\mathrm{Ca}^{2+}$ caused a decrease in the viability of Mycobacterium tuberculosis (Malik et al., 2001). Calcium also has been shown to be an effective macrophage activator, favoring the fusion between the parasitophorous vacuoles with lysosomes (Sibley et al., 1991). On the other hand, in the present study scant release of NO was observed in cells treated with $\mathrm{Mg}^{2+}$ in accordance with another study which suggested that $\mathrm{Mg}^{2+}$ deficiency enhances $\mathrm{NO}$ production via iNos by alveolar macrophages isolated from rats (Yokoyama et al., 2003). In addition, it has been demonstrated that $\mathrm{Mg}^{2+}$ dependent ecto-ATPase activity in Leishmania tropica may play a crucial role in enabling the parasite to avoid the microbicidal activity of macrophages (MeyerFernandes et al., 1997).

Resident macrophages did not up-regulate their NO production in response to any stimuli applied, though these macrophages were able to inhibit the proliferation of $L$. major when pre-treated with either LPS, SLA, CaI or CaI+SLA, suggesting that in resident macrophages microbicidal activity through nitrogen reactive species may not play a pivotal role in murine leishmaniasis control. A study comparing resident and inflammatory peritoneal macrophages demonstrated that regulation of phagocytosis by genetically-determined mechanisms is different between those two types of cells (Reichner et al., 2001).

In the present study a significant increase in NO release and a greater ability to inhibit $L$. major proliferation by inflammatory macrophages treated with LPS or SLA alone or in combination were observed. Therefore, treatment of both resident and inflammatory macrophages leads to inhibition of parasite proliferation, suggesting meditated microbicidal activities by LPS. Some authors have attributed microbicidal activities to LPS alone (Cunha et al., 1993) or interferon gama (IFN- $\gamma)$ and LPS together not only for L. major but also for other intracellular parasites, as well (Sibley et al., 1991, Tsang et al., 2000). It has been demonstrated that $\mathrm{Ca}^{2+}$ is involved in cell signaling induced by LPS, which regulates NO production by murine RAW 264.7 macrophages, as was observed in the present study when inflammatory macrophages were activated by CaI+LPS (Vivancos and Moreno, 2002).

In macrophages treated with LPS alone or in combination, cell spreading over the dish was observed. This is in keeping with other data demonstrating that cells treated with LPS presented more actin filaments in the periphery, which characterizes the macrophages activation (Chakravortty and Nanda Kumar, 2000). Inflammatory macrophages treated with CaI+LPS, $\mathrm{CaI}+\mathrm{Mg}^{2+}$ and LPS + SLA (data not shown), as well as resident macrophages treated with $\mathrm{CaI}+\mathrm{Mg}^{2+}$ and $\mathrm{CaI}+\mathrm{LPS}$ and $\mathrm{J} 774$ cells treated with CaI, SLA and LPS+SLA (data not shown) presented greater number of cytoplasmic elongations, suggesting that calcium ionophore and LPS significantly influence cytoskeleton reorganization. Recently, it was demonstrated that J774 cells activated in vitro with $\mathrm{CaI}$ increased myosin expression and NO production and also presented greater number of cytoplasmic elongations suggesting the importance of motor molecules on effect functions of these cells (Reis et al., 2001).

The results of this study demonstrated the importance of calcium in decreasing L. major proliferation inside murine macrophages. However, $\mathrm{Mg}^{2+}$ seemed to increase parasite proliferation as observed in inflammatory macrophages, suggesting that L. major may use a $\mathrm{Mg}^{2+}$ dependent pathway to proliferate and evade microbicidal activity.

\section{ACKNOWLEDGMENTS}

This research was supported by grants from the Conselho Nacional de Desenvolvimento Científico e Tecnológico (CNPq).

\section{REFERENCES}

ALEXANDER J, RUSSELL DG (1992) The interaction of Leishmania species with macrophages. Adv Parasitol 31: 175-254

AUGER M J, ROSS JA (1991) The biology of macrophage In: LEWIS CE, MCGEE JOD (eds) The Macrophage. Oxford: Oxford University Press, pp: 1-74 
BUCHMÜLLER-ROUILLER Y，MAUËL J (1991) Macrophage activation for intracellular killing as induced by calcium ionophore. J Immunol 146: 217223

CARRERAS MC, SCHOPPER F, LISDERO C, RIOBO N, POSEROSO JJ (2000) Mitocondrial function and nitric oxide utilization. Biological Research 33: 177-183

CHAKRAVORTTY D, NANDA KUMAR KS (2000) Bacterial lipopolysaccharide induces cytoskeletal rearrangement in small intestinal lamina propria fibroblasts: Actin assembly is essential for lipopolysaccharide signaling. Biochim Biophys Acta 1500: $125-136$

CHANG KP, REED SG, MCGWIRE BX, SOONG L (2003) Leishmania model for microbial virulence: The relevance of parasite multiplication and pathoantigenicity. Acta Tropica 85: 375-390

CUNHA FQ, ASSREUY J, MONCADA S, LIEW FY (1993) Phagocytosis and induction of nitric oxide syntase in murine macrophages. Immunology 79: 408411

DRAPIER JC, WIETZERBIN J, HIBBS JR JB (1988) Interferon-gamma and tumor necrosis factor induce the L-arginine-dependent cytotoxic effector mechanism in murine macrophages. Eur J Immunol 18: 1587-1592

HUANG FP, NIEDBALA W, WEI XQ, XU D, FENG G, ROBINSON H, LAM C, LIEW FY (1998) Nitric oxide regulates Th1 cell development through the inhibition of IL-12 synthesis by macrophages.. Eur J Immunol 28: 4062-4070

LOWRY OH, ROSEBROUGH NJ, FARR AL, RANDALL RJ (1951) Protein measurement with the folin phenol reagent. J Biol Chem 193: 265-275

MALIK ZA, IYER SS, KUSNER DJ (2001) Mycobacterium tuberculosis phagosomes exhibit altered calmodulin-dependent signal transduction: Contribution to inhibition of phagosome-lysosome fusion and intracellular survival in human macrophages. J Immunol 166: 3392-3401

MARTÍNEZ J, SÁNCHEZ T, MORENO JJ (2000) Regulation of prostaglandin $\mathrm{E}_{2}$ production by the superoxide radical and nitric oxide in mouse peritoneal macrophages. Free Rad Res 32: 303-311

MEYER-FERNANDES JR, DUTRA PML, RODRIGUES CO, SAAD-NEHME J, LOPES AH (1997) Mgdependent Ecto-ATPase activity in Leishmania tropica.. Ach Biochem Biophys 341: 40-46

MURRAY HW, NATHAN CF (1999) Macrophage microbicidal mechanisms in vivo: Reactive nitrogen versus oxygen intermediates in the killing of intracellular visceral Leishmania donovani.. J Exp Med 189: $741-746$
PROBST P, STROMBERG E, GHALIB HW, MOZEL M, BADARO R, REED SG, WEBB JR (2001) Identification and characterization of $\mathrm{T}$ cell-stimulating antigens from Leishmania by CD4 $\mathrm{T}$ cell expression cloning. J Immunol 166: 498-505

REICHNER JS, FITZPATRICK PA, WAKSHULL E, ALBINA JE (2001) Receptor-mediated phagocytosis of rat macrophages is regulated differentially for opsonized particles and non-opsonized particles containing beta-glucan. Immunology 104: 198-206

REIS DS, SOUZA MA, MINEO JR, ESPÍNDOLA FS (2001) Myosin V and iNOS expression is enhanced in J774 murine macrophages treated with IFN-g. Braz J Med Biol Res 34: 221-226

ROGERS KA, DEKREY GK, MBOW ML, GILLESPIE RD, BRODSKYN CI, TITUS RG (2002) Type 1 and type 2 responses to Leishmania major. FEMS Microbiol Letters 209: 1-7

RUBBO H, BATTHYANY C, RADI R (2000) Nitric oxide: Oxygen radical interactions in artherosclerosis. Biological Research 33: 167-175

SCOTT P, PEARCE E, NATOVITZ P, SHER A (1987) Vaccination against cutaneous leishmaniasis in a murine model. I. Induction of protective immunity with a soluble extract of promastigotes. J Immunol 139: 221-227

SIBLEY LD, ADAMS LB, FUKUTOMI Y, KRAHENBUHL JL (1991) Tumour necrosis factoralpha triggers antitoxoplasmal activity of IFN-gamma primed macrophages. J Immunol 147: 2340-2345

TSANG AW, OESTERGAARD K, MYERS JT, SWANSON JA (2000) Altered membrane trafficking in activated bone marrow-derived macrophages. J Leuk Biol 68: 487-494.

TURCO SJ, DESCOTEAUX A (1992) The lipophosphoglycan of Leishmania parasites. Ann Rev Microbiol 46: 65-94

VIVANCOS M, MORENO JJ (2002) Role of $\mathrm{Ca}^{2+}$. independent phospholipase $\mathrm{A}_{2}$ and cyclooxygenase/ lipoxygenase pathways in the nitric oxide production by murine macrophages stimulated by lipopolysaccharides. Nitric Oxide: Biol Chem 6: 255-262

VOULDOUKIS J, MORENO VR, DUGAS B, QUAAZ F, BECHEREL P, DEBRE P, MONCADA S, MOSSALAYI MD (1995) The killing of Leishmania major by human macrophages is mediated by nitric oxide induced after ligation of the FceRII/CD23 surface antigen.. Proc Nat Aca Sci USA 92: 7804-7808

YOKOYAMA T, OONO H, MIYAMOTO A, ISHIGURO S, NISHIO A (2003) Magnesium-deficient medium enhances NO production in alveolar macrophages isolated from rats. Life Sci 72: 1247-1257 